- FINANSE I PRA WO FINANSO WE.

- Journal of Finance and Financial Law $•$

Czerwiec/June 2017 • vol. 2(14): 23-39

http://dx.doi.org/10.18778/2391-6478.2.14.03

\title{
EFEKTYWNOŚĆ PRODUKTÓW EMERYTALNYCH OFEROWANYCH PRZEZ ZAKŁADY UBEZPIECZEŃ NA ŻYCIE NA PRZYKŁADZIE IKE
}

\author{
Łukasz Dopierała \\ Wydział Ekonomiczny \\ Uniwersytet Gdański
}

\begin{abstract}
Streszczenie
Celem niniejszego artykułu jest określenie efektywności produktów emerytalnych oferowanych przez zakłady ubezpieczeń na życie z punktu widzenia klientów tych instytucji, na przykładzie indywidualnych kont emerytalnych. W artykule zaprezentowano znaczenie produktów oferowanych przez zakłady ubezpieczeń na życie w polskim systemie emerytalnym. Scharakteryzowano zasady funkcjonowania indywidualnych kont emerytalnych oferowanych przez ubezpieczycieli oraz ich wpływ na przydatność tej formy zabezpieczenia z punktu widzenia konsumentów. Ponadto zaprezentowano wyniki badania efektywności inwestycyjnej osiąganej przez ubezpieczeniowe fundusze kapitałowe działające w ramach IKE w latach 2005-2015. Badania wskazują, że oferowanie IKE jako samodzielnych produktów ubezpieczeniowych należy uznać za rozwiązanie mało korzystne z punktu widzenia osób gromadzących oszczędności emerytalne.
\end{abstract}

Słowa kluczowe: IKE, emerytura, ubezpieczenia, efektywność, fundusze.

JEL Class: G22, G23, J32. 


\section{WPROWADZENIE}

W świetle panujących trendów demograficznych problematyka zabezpieczenia dochodów w okresie starości stanowi istotne oraz aktualne zagadnienie badawcze. W związku z prognozowanym starzeniem się polskiego społeczeństwa, repartycyjna część systemu emerytalnego borykać się będzie w przyszłości z większym niedoborem środków finansowych. $Z$ systemowego punktu widzenia coraz istotniejszym elementem zabezpieczenia emerytalnego powinny zatem stawać się dobrowolne plany emerytalne. Wykorzystanie dodatkowych form zabezpieczenia emerytalnego związane jest z odłożeniem bieżącej konsumpcji na rzecz osiągania wyższych dochodów w przyszłości, a więc z procesem inwestowania.

Celem niniejszego artykułu jest określenie efektywności produktów emerytalnych oferowanych przez zakłady ubezpieczeń na życie z punktu widzenia klientów tych instytucji, na przykładzie indywidualnych kont emerytalnych (IKE). Zakłady ubezpieczeń oferują bowiem szereg produktów dostępnych w ramach kwalifikowanych programów emerytalnych, a wśród nich IKE stanowi instrument wykorzystywany najpowszechniej. Autor stawia tezę, że oferowanie IKE jako samodzielnych produktów ubezpieczeniowych należy uznać za rozwiązanie mało korzystne $\mathrm{z}$ punktu widzenia osób gromadzących oszczędności emerytalne.

W artykule zaprezentowano znaczenie produktów oferowanych przez zakłady ubezpieczeń na życie w polskim systemie emerytalnym. Scharakteryzowano zasady funkcjonowania IKE oferowanych przez ubezpieczycieli oraz ich wpływ na przydatność tej formy zabezpieczenia z punktu widzenia konsumentów. Ponadto zaprezentowano wyniki badania efektywności inwestycyjnej osiąganej przez ubezpieczeniowe fundusze kapitałowe (UFK) działające w ramach IKE w latach 2005-2015.

Artykuł opiera się na badaniach literaturowych oraz części empirycznej przygotowanej w oparciu o dane udostępnione przez Komisję Nadzoru Finansowego (KNF) oraz bazę danych wycen jednostek UFK, dostarczoną przez Analizy Online S.A. W badaniach wykorzystano ponadto dane dostarczone przez Thomson Reuters na podstawie umowy o współpracy między Thomson Reuters a Uniwersytetem Gdańskim.

Zastosowanymi w artykule metodami badawczymi są: analiza literaturowa, analiza aktów prawnych, analiza statystyczna oraz analiza wskaźnikowa efektywności inwestycyjnej, wywodząca się z klasycznej teorii portfela.

Należy dodać, że prowadzone badania finansowane były z dotacji Ministerstwa Nauki i Szkolnictwa Wyższego dla Uniwersytetu Gdańskiego przeznaczonej na badania i rozwój młodych naukowców - nr projektu: 538-3300-B222-16. 


\section{PRODUKTY EMERYTALNE OFEROWANE PRZEZ ZAKŁADY UBEZPIECZEŃ NA ŻYCIE JAKO ELEMENT TRZECIEGO FILARU POLSKIEGO SYSTEMU EMERYTALNEGO}

Polski system emerytalny, skonstruowany w ramach reformy z 1999 r. opierał się na koncepcji zaproponowanej w 1998 r. przez Bank Światowy ${ }^{1}$ i był połączeniem umowy międzypokoleniowej oraz systemu kapitałowego, co w przyszłości miało zapewnić jego stabilność finansową. Przyjął on formę systemu o zdefiniowanej składce. Wprowadzenie trzech filarów emerytalnych miało na celu rozproszenie ryzyk - politycznego, demograficznego oraz rynkowego. Początkowo zarówno pierwszy jak i drugi filar były w pełni obowiązkowe ${ }^{2}$. Trzeci filar miał mieć charakter w pełni dobrowolny.

W polskim systemie emerytalnym pierwszym sformalizowanym (kwalifikowanym) rozwiązaniem dostępnym $\mathrm{w}$ ramach trzeciego filaru były pracownicze programy emerytalne (PPE) - odpowiedniki działających w Europie Zachodniej oraz $\mathrm{w}$ Stanach Zjednoczonych occupational pension schems. PPE tworzone są przez pracodawców dla pracowników, którzy przystępują do nich na podstawie zawartej umowy. Pierwsze PPE zostały uruchomione w roku 1999 [Szczepański 2012: 4].

Ważnym etapem rozwoju polskiego systemu emerytalnego było wzbogacenie trzeciego filaru o kolejne instrumenty gromadzenia dodatkowych oszczędności emerytalnych. Pierwszym z nich były powołane w 2004 r. IKE, które początkowo umożliwiały indywidualne oszczędzanie na emeryturę w czterech typach instytucji [Ustawa z dnia 20 kwietnia 2004 r. o indywidualnych kontach emerytalnych]:

- funduszach inwestycyjnych,

- podmiotach prowadzących działalność maklerską,

- zakładach ubezpieczeń,

- bankach.

Istotnym elementem działalności IKE, który miał zachęcać do korzystania $\mathrm{z}$ tego instrumentu, było zwolnienie z podatku od zysków kapitałowych. Jednocześnie wprowadzono roczny limit wpłat na IKE który stanowił $150 \%$ prognozowanego średniego wynagrodzenia w kraju. Każda osoba mogła posiadać maksymalnie jedno IKE.

W kolejnych latach, w odpowiedzi na niewielkie zainteresowanie dobrowolnymi formami zabezpieczenia emerytalnego, wprowadzono dalsze modyfi-

${ }^{1}$ Była to tzw. pierwsza koncepcja wielofilarowego (multi-pillar) systemu emerytalnego, która opierała się na trzech filarach emerytalnych: pierwszy - obowiązkowa część repartycyjna zarządzana przez państwo, drugi - obowiązkowa część kapitałowa zarządzaną przez podmioty prywatne, trzeci - dobrowolne, uzupełniające plany emerytalne [Holzmann 1998: 6-10].

${ }^{2}$ Reforma z 2014 r. umożliwiła rezygnację z odprowadzania składek do otwartych funduszy emerytalnych (OFE) stanowiących drugi filar systemu. W momencie pisania niniejszego artykułu (marzec 2017 r.) istnieją zaawansowane plany całkowitej likwidacji tego elementu systemu emerytalnego. 
kacje trzeciego filaru. Do najważniejszych z nich należy zaliczyć zwiększenie wpłat na IKE do $300 \%$ prognozowanego średniego wynagrodzenia w kraju ustawą z 2008 r. [Ustawa z dnia 6 listopada 2008 r. o zmianie ustawy o indywidualnych...] oraz wprowadzenie w 2012 r. możliwości oszczędzania poprzez indywidualne konta zabezpieczenia emerytalnego (IKZE). Możliwość oszczędzania na IKZE uregulowana została poprzez nowelizację ustawy o indywidualnych kontach emerytalnych, przy czym nastąpiła zmiana nazwy ustawy [Ustawa z dnia 20 kwietnia 2004 r. o indywidualnych kontach emerytalnych oraz indywidualnych...]. IKZE mogą być prowadzone przez instytucje tego samego typu co IKE. Znowelizowana ustawa umożliwiła prowadzenie obu typów kont przez dobrowolne fundusze emerytalne (DFE). Cechą odróżniającą IKZE od IKE jest rodzaj ulgi podatkowej przysługujący ubezpieczonemu. Oszczędzający na IKZE może bowiem odliczyć od podstawy opodatkowania wpłaty na IKZE dokonane przez niego w danym w roku podatkowym. Należy jednak podkreślić, że dla IKZE ustanowiono znacznie niższy limit wpłat, gdyż nie mogą one przekroczyć w roku kalendarzowym kwoty odpowiadającej 1,2-krotności przeciętnego prognozowanego wynagrodzenia miesięcznego $\mathrm{w}$ gospodarce narodowej na dany rok, określonego w ustawie budżetowej [Ustawa z dnia 20 kwietnia 2004 r. o indywidualnych kontach emerytalnych oraz indywidualnych...].

Można przyjąć, że do 2005 r. rynek dobrowolnych ubezpieczeń emerytalnych w Polsce znajdował się jeszcze w początkowym etapie swojego rozwoju. Na koniec 2004 r. w całym kraju istniało tylko 309 PPE, w których uczestniczyło ok. 109 tys. osób. Kolejny rok był przełomowy ponieważ liczba funkcjonujących programów zwiększyła się do 906, a liczba uczestników wzrosła o ponad $100 \%$ (zob. rys. 1).

Od początku funkcjonowania dobrowolnych forma zabezpieczenia emerytalnego istotnym elementem oferty były produkty zakładów ubezpieczeń na życie. W przypadku PPE należały do nich ubezpieczenia grupowe $\mathrm{z}$ ubezpieczeniowym funduszem kapitałowym. Liczba osób korzystających z tej formy zabezpieczenia emerytalnego nie przekroczyła jednak w całej dotychczasowej historii funkcjonowania 150 tys.

Produkty zakładów ubezpieczeń wykorzystywane są znacznie szerzej w ramach indywidualnych form zabezpieczenia emerytalnego. Umowa o zawarcie grupowego ubezpieczenia na życie $w$ ramach PPE jest bowiem zawierana $\mathrm{z}$ inicjatywy pracodawcy. W przypadku indywidualnych form zabezpieczenia takich jak IKE oraz IKZE inicjatorem zabezpieczenia jest sam zainteresowany, do którego można dotrzeć wykorzystując dostępne kanały sprzedażowe. Zakłady ubezpieczeń działają aktywnie na polu sprzedaży oferowanych produktów, dlatego dotarły do szerszego grona osób zainteresowanych zabezpieczeniem emerytalnym, niż pozostałe instytucje (zob. rys. 2 oraz rys. 3 ). 


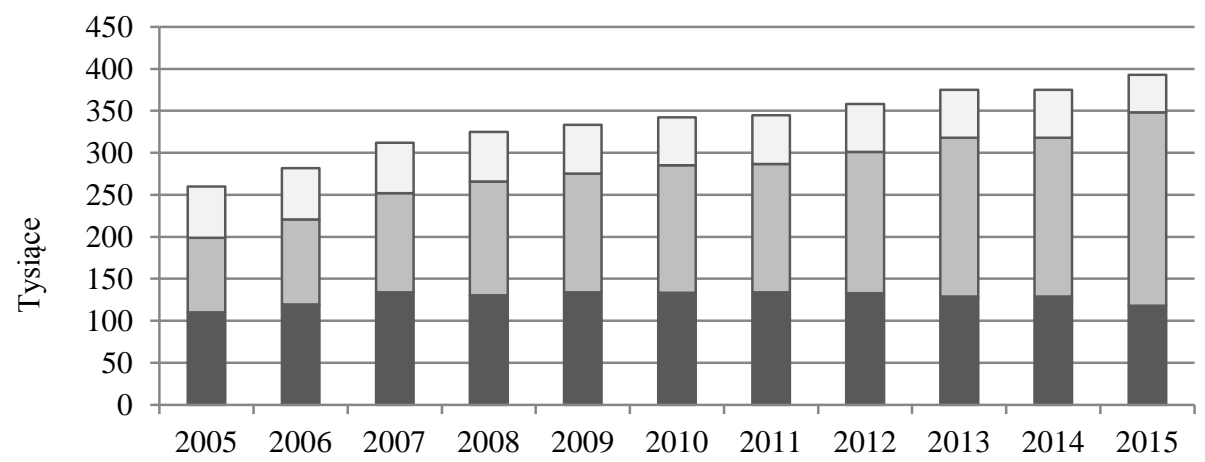

$\square \mathrm{w}$ formie pracowniczego funduszu emerytalnego

$\square \mathrm{w}$ formie funduszu inwestycyjnego

${ }_{\mathrm{W}}$ formie grupowego ubezpieczenia na życie z ubezpieczeniowym funduszem kapitałowym

Rysunek 1. Liczba uczestników PPE w podziale na formy w latach 2005-2015

Źródło: opracowanie własne na podstawie danych KNF: http://www.knf.gov.pl [dostęp: 11.03.2017].

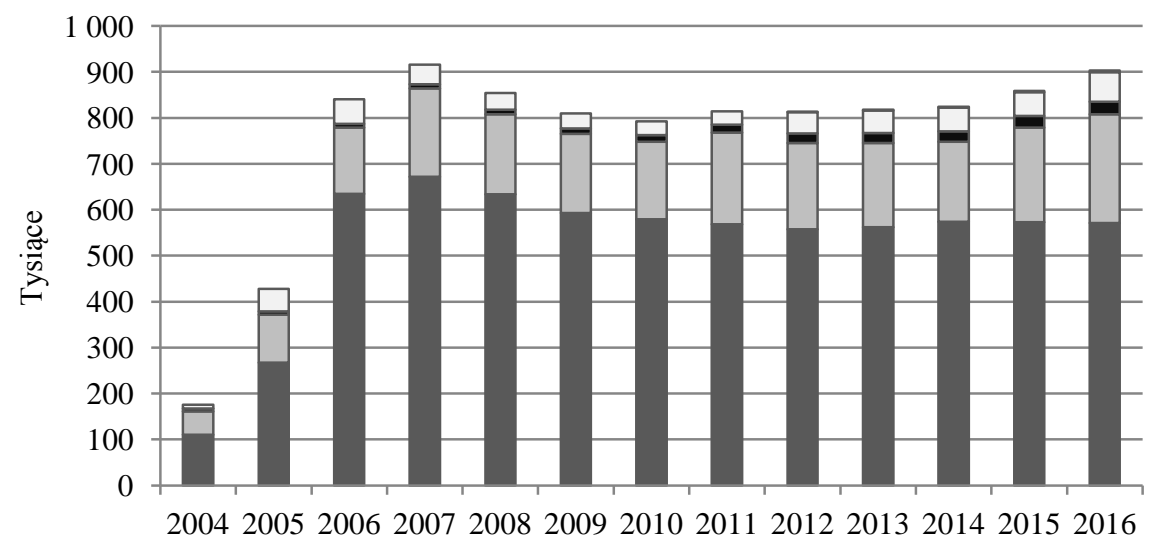

$\square$ dobrowolne fundusze emerytalne

$\square$ banki

- podmioty prowadzące działalność maklerską $\square$ fundusze inwestycyjne

zakłady ubezpieczeń

Rysunek 2. Liczba IKE funkcjonujących według typów instytucji prowadzących konta w latach 2005-2016

Źródło: opracowanie własne na podstawie danych KNF: http://www.knf.gov.pl [dostęp: 11.03.2017]. 


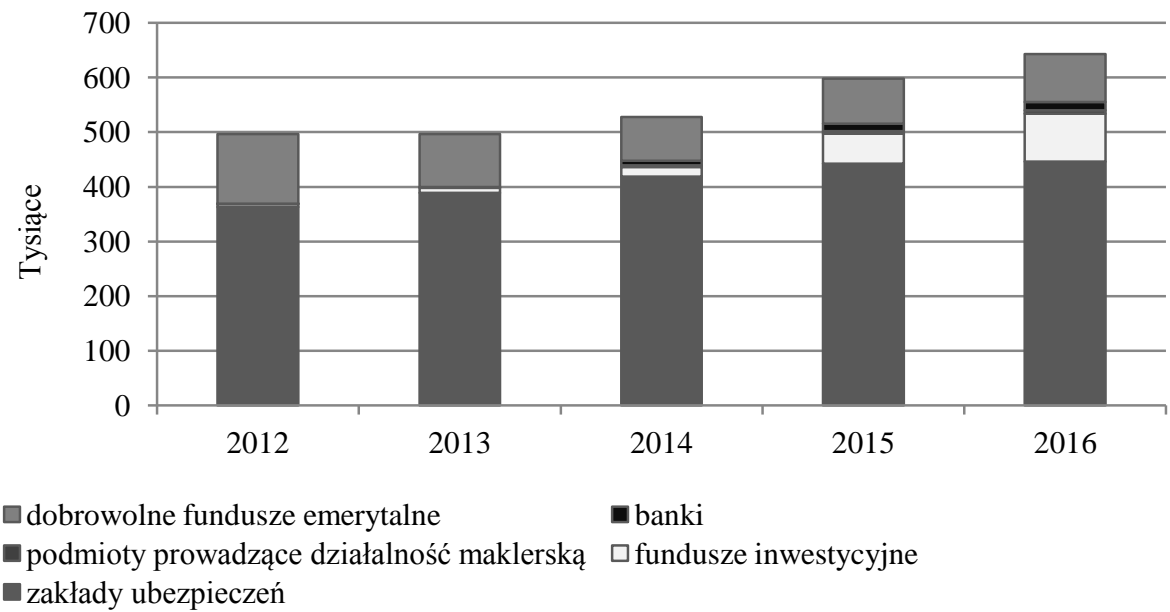

Rysunek 3. Liczba IZKE funkcjonujących według typów instytucji prowadzących konta w latach 2005-2016

Źródło: opracowanie własne na podstawie danych KNF: http://www.knf.gov.pl [dostęp: 11.03.2017].

Najliczniejszą grupą funkcjonujących IKE, były te prowadzone przez zakłady ubezpieczeń, działające w formie ubezpieczenia na życie z UFK. W roku $2007 \mathrm{r}$. istniało ponad 670 tys. takich kont. W następnych latach liczba ta spadła, jednak na koniec analizowanego okresu (2016 r.) IKE w zakładach ubezpieczeń nadal były najpowszechniejsze - funkcjonowało ich bowiem ponad 570 tys. Warto dodać, że biorąc pod uwagę liczbę osób korzystających z danej formy zabezpieczenia, IKE w zakładach ubezpieczeń są najistotniejszym elementem trzeciego filaru emerytalnego w Polsce. Liczba IKE prowadzonych w pozostałych typach instytucji jest dużo mniejsza.

Analizując liczbę IKZE w podziale na instytucje prowadzące, zauważa się, tak jak w przypadku IKE, że największy udział mają konta prowadzone w zakładach ubezpieczeń. Liczba IKZE w formie ubezpieczenia na życie z UFK przekracza 440 tys. Tak jak w przypadku IKE, liczba IKZE prowadzonych przez pozostałe typy instytucji jest dużo mniejsza. Sposób funkcjonowania produktów dostępnych $\mathrm{w}$ ramach obu form jest podobny. W zasadzie różnią się one od siebie rodzajem dostępnej ulgi podatkowej oraz limitem wpłat.

Należy nadmienić, że znaczna część IKE oraz IKZE prowadzonych przez zakłady ubezpieczenie nie jest systematycznie zasilana nowymi składkami. Udział aktywnych IKE w ogólnej ich liczbie w przypadku zakładów ubezpieczeń rokrocznie zawiera się w przedziale $25-30 \%$. W przypadku IKZE udział kont aktywnych jest podobny i wynosi ok. $25 \%$. 
Istotną informacją jest również wartość aktywów zgromadzonych przez zakłady ubezpieczeń $\mathrm{w}$ ramach poszczególnych form zabezpieczenia emerytalnego. W przypadku IKE oraz PPE wartość zgromadzonych aktywów przekracza dla każdej z form zabezpieczenia 2 mld PLN. Aktywa zgromadzone w IKZE, ze względu na krótszy okres funkcjonowania, były niższe i wynosiły blisko $400 \mathrm{mln}$ PLN.

\section{ZASADY FUNKCJONOWANIA IKE OFEROWANYCH PRZEZ ZAKŁADY UBEZPIECZEŃ}

Zakłady ubezpieczeń oferują IKE w formie ubezpieczenia na życie z UFK, które łączy w sobie dwie funkcje - ochronną oraz oszczędnościową. Zgodnie z polskim prawem ubezpieczenie jest umownym obowiązkiem dokonania świadczenia przez ubezpieczyciela na rzecz ubezpieczonego w razie zajścia przewidzianego w umowie wypadku. Jednocześnie ubezpieczający zobowiązany jest do zapłacenia składki. Ubezpieczenie na życie klasyfikowane jest jako ubezpieczenie gospodarcze osobowe. Cechą charakterystyczną ubezpieczeń osobowych jest zobowiązanie się ubezpieczyciela do wypłacenia umówionej sumy pieniężnej, renty lub innego świadczenia, w razie zajścia przewidzianego w umowie wypadku w życiu osoby ubezpieczonej [Ustawa z dnia 23 kwietnia 1964 r. Kodeks cywilny].

W przypadku klasycznych ubezpieczeń na życie o charakterze oszczędnościowym, część wpłaconej składki ubezpieczeniowej jest lokowana przez zakład ubezpieczeń na rynkach finansowych. To powoduje, że działalność lokacyjna jest integralną częścią działalności techniczno-ubezpieczeniowej ubezpieczyciela i jest ona prowadzona na jego rachunek i ryzyko [Kania 2011: 233]. Ubezpieczenia na życie z UFK różnią się od ubezpieczeń klasycznych tym, że tylko część składki pokrywa ryzyko ubezpieczeniowe oraz koszty zakładu ubezpieczeń z tytułu prowadzenia działalności ubezpieczeniowej. Pozostała część jest inwestowana $\mathrm{w}$ ramach UFK i ma na celu zwiększenie aktywów ubezpieczającego. Ryzyko związane $\mathrm{z}$ wynikiem działalności lokacyjnej obarcza w tym przypadku ubezpieczonego [Szczepańska 2011: 23].

Wyodrębniony UFK jest zatem charakterystycznym elementem umowy niedostępnym w przypadku ubezpieczeń innego typu. Definiowany jest on jako wydzielony fundusz aktywów, stanowiący rezerwę tworzoną ze składek ubezpieczeniowych, inwestowany $\mathrm{w}$ sposób określony $\mathrm{w}$ umowie ubezpieczenia [Ustawa z dnia 11 września 2015 r. o działalności ubezpieczeniowej...]. Nie jest on osobą prawną, zatem nie jest podmiotem samodzielnym. Aktywa zgromadzone w UFK stanowią własność ubezpieczyciela. Jest to jednak majątek wyodrębniony pod względem księgowym. To ubezpieczyciel decyduje o sposobie 
lokowania środków. Ubezpieczający, ubezpieczony, uposażony ani inne osoby nie mogą żądać wydzielenia poszczególnych aktywów przypisanych do danego funduszu ${ }^{3}$. Ubezpieczający może jednak dokonać wyboru określonego funduszu i poprzez to mieć wpływ na sposób zarządzania powierzonymi aktywami. Ze względu na specyfikę funkcjonowania polis ubezpieczeń na życie UFK mają formę podobną do funduszy inwestycyjnych otwartych (FIO), oferowanych przez towarzystwa funduszy inwestycyjnych. Mogą one wydawać dowolną liczbę jednostek uczestnictwa, a także umarzać je na żądanie klienta.

Ponieważ aktywa zgromadzone w UFK stanowią własność zakładu ubezpieczeń, w przypadku upadłości ubezpieczyciela mogłyby one wchodzić w skład masy upadłościowej, bez żadnych preferencji dla osób posiadających polisy. Zgodnie z rozporządzeniem ministra finansów przychody i koszty oraz aktywa i pasywa danego UFK nie mogą jednak być kompensowane $\mathrm{z}$ innymi przychodami i kosztami oraz aktywami i pasywami zakładu ubezpieczeń [Rozporządzenie Ministra Finansów z dnia 12 kwietnia 2016 r. w sprawie szczególnych zasad rachunkowości...].

Warto również dodać, że świadczenia z tytułu ubezpieczeń na życie gwarantowane są przez Ubezpieczeniowy Fundusz Gwarancyjny w wysokości 50\% wierzytelności, jednak do kwoty nie większej niż równowartość w złotych 30000 euro, według średniego kursu ogłaszanego przez Narodowy Bank Polski obowiązującego w dniu ogłoszenia upadłości [Ustawa z dnia 22 maja 2003 r. o ubezpieczeniach obowiązkowych...].

Należy także zwrócić uwagę na kwestie dotyczące egzekucji sądowej oraz opodatkowania w przypadku UFK. Ponieważ jednostki uczestnictwa funduszy ubezpieczeniowych są własnością zakładu ubezpieczeń, nie podlegają one egzekucji na poczet zobowiązań ubezpieczającego lub ubezpieczonego. Również wypłata świadczenia na rzecz uposażonego wyłączona jest spod egzekucji nawet do wysokości $75 \%$ wypłaconych środków. Należy podkreślić, że w przypadku śmierci ubezpieczonego osoba uposażona otrzyma środki bez konieczności postępowania spadkowego. Uniknie jednocześnie podatku od spadku i darowizn. Powyższe zalety UFK nie występują w przypadku FIO.

W ubezpieczeniach z UFK, oferowanych jako IKE ważnym aspektem z punktu widzenia klienta jest wysokość oraz podział składki, które świadczą o znaczeniu funkcji ochronnej oraz oszczędnościowej. W przypadku IKE minimalna składka ubezpieczeniowa brutto ustalana jest na niskim poziomie. $\mathrm{Na}$ koniec 2015 r., w zależności od zakładu ubezpieczeń, minimalna składka wynosiła od 50 PLN do 3600 PLN rocznie. Większość ubezpieczycieli umożliwia swoim klientom opłacanie składek z różną częstotliwością. Do dyspozycji są najczęściej raty miesięczne oraz kwartalne bądź też roczne wpłaty jednorazowe.

${ }^{3}$ Uposażony to beneficjent świadczenia, jakie ma wypłacić ubezpieczyciel w przypadku śmierci ubezpieczonego [Kucharski 2015: 47-63]. 
Podział składki na część ochronną i oszczędnościową uzależniony jest od przebiegu ubezpieczenia oraz zakresu ochrony ubezpieczeniowej. Jeżeli IKE funkcjonuje jako umowa dodatkowa do pakietu ubezpieczeń, to składka ochronna jest ustalana indywidualnie. Składka oszczędnościowa odkładana na IKE również ustalana jest osobno dla każdego ubezpieczonego, w zależności od jego możliwości finansowych, przy czym np. dla IKE w Nationale-Nederlanden TUnŻ minimalna wysokość składki oszczędnościowej określona jest na poziomie 600 PLN rocznie. Jeżeli IKE oferowane jest jako samodzielna polisa, to zakłady ubezpieczeń deklarują, że całość składki ma charakter oszczędnościowy.

Składka opłacana przez ubezpieczającego obciążona jest jednak szeregiem kosztów oraz opłat. W przypadku ubezpieczeń dostępnych w ramach IKE największe znaczenie posiadają następujące rodzaje opłat:

- opłata za ryzyko ubezpieczeniowe;

- opłata alokacyjna (wstępna);

- opłata za zarządzanie aktywami w ramach UFK;

- opłata operacyjna (transakcyjna) za przeniesienie środków między UFK;

- opłata likwidacyjna (za wykup/zwrot środków).

Opłata za ryzyko ubezpieczeniowe w przypadku ubezpieczeń oferowanych jako IKE ustalana jest na bardzo niskim poziomie i wynosi kilkadziesiąt złotych w skali roku.

Opłata alokacyjna ustalana jest procentowo w stosunku do składki i naliczana od każdej zapłaconej składki. Na koniec 2015 r. w ramach produktów oferowanych jako IKE, opłata ta ustalana była maksymalnie na poziomie $5 \%$. W zakładach ubezpieczeń, w których IKE stanowi umowę dodatkową do pakietu ubezpieczeń na życie, opłata ta nie była pobierana. TU Allianz Życie Polska uzależniał wysokość opłaty alokacyjnej od czasu trwania umowy. Najwyższa jest w pierwszych trzech latach $-3 \%$, by w kolejnych trzech spaść o jeden punkt procentowy, a od siódmego roku trwania umowy wynieść $0 \%$.

Opłaty za zarządzanie aktywami w ramach UFK uzależnione są od stosowanego modelu zarządzania procesem inwestycyjnym. UFK mogą być bowiem zarządzane wewnętrznie lub zewnętrznie. Zarządzanie wewnętrzne polega na tym, że zakład ubezpieczeń całkowicie samodzielnie tworzy i zarządza zdywersyfikowanym portfelem inwestycyjnym funduszu. Zarządzanie zewnętrzne polega na powierzeniu działań związanych z procesem inwestycyjnym podmiotom zewnętrznym, W przypadku IKE powszechnie stosowana jest eksternalizacja pośrednia, która polega na zakupie przez zakład ubezpieczeń produktów inwestycyjnych - jednostek uczestnictwa $\mathrm{FIO}^{4}$.

\footnotetext{
${ }^{4}$ Analiza oferty zakładów ubezpieczeń wskazuje, że najpowszechniej stosowaną metodą zarządzania na koniec 2015 r. był model mieszany. Sześć zakładów ubezpieczeń prowadzących IKE posiadało zarówno UFK zarządzane wewnętrznie, jak i zewnętrznie. Cztery zakłady ubezpieczeń
} 
Analiza prospektów informacyjnych funduszy znajdujących się w ofercie zakładów ubezpieczeń na koniec 2015 r. wskazuje, że nominalne opłaty za zarządzanie aktywami w przypadku UFK zarządzanych zewnętrznie są średnio niższe niż w UFK zarządzanych wewnętrznie. Prawidłowość ta zachodzi w przypadku funduszy akcyjnych (średnia opłata za zarządzanie w skali roku dla funduszy zarządzanych wewnętrznie - 3,55\%, dla zarządzanych zewnętrznie $-2,86 \%$ ) oraz mieszanych (zarządzane wewnętrznie $-3,17 \%$, zarządzane zewnętrznie $-2,22 \%$ ). Jedynie $w$ grupie funduszy obligacyjnych sytuacja jest odwrotna (zarządzane wewnętrznie - 1,64\%, zarządzane zewnętrznie - 2,16\%). Fundusze zarządzane zewnętrznie muszą jednak niekiedy uiszczać opłatę za zarządzanie ustalaną przez towarzystwa funduszy inwestycyjnych zarządzające FIO, których jednostki stanowią aktywa UFK. Te opłaty ostatecznie ponoszone są przez klientów, a mimo to nie są im bezpośrednio prezentowane.

Mniejsze znaczenie dla klienta ma opłata operacyjna, która ustalana jest kwotowo i pobierana za zrealizowanie zlecenia transferu środków lub zmianę alokacji składki pomiędzy UFK. Pobranie tej opłaty następuje poprzez umorzenie na rachunku odpowiedniej liczby jednostek uczestnictwa. Należy jednak zaznaczyć, iż większość zakładów ubezpieczeń umożliwia bezpłatne przeniesienie środków między UFK od kilku do kilkunastu razy w ciągu roku.

Duże znaczenie z punktu widzenia oszczędzającego ma natomiast wysokość opłaty likwidacyjnej. Jest ona najczęściej ustalana procentowo i pobierana poprzez umorzenie na rachunku odpowiedniej liczby jednostek lub potrącenie środków pochodzących z umorzenia jednostek uczestnictwa w wyniku zwrotu środków. Generalnie pobieranie tej opłaty stało się powodem krytyki zakładów ubezpieczeń. W przypadku ubezpieczeń z UFK zdarzały się bowiem sytuacje, gdy zakład ubezpieczeń ustalał tę opłatę na poziomie nawet $100 \%$ zgromadzonych środków. W teorii opłata likwidacyjna powinna występować w ubezpieczeniach posiadających nie tylko charakter oszczędnościowy, ale również ochronny. Ubezpieczający odstępujący od tego typu ubezpieczenia musi liczyć się z pokryciem części kosztów ochrony ubezpieczeniowej wszystkich ubezpieczonych. Ponadto, opłaty tego typu mają na celu ograniczenie pochopności decyzji inwestycyjnych. W przypadku ubezpieczeń na życie z UFK, znaczna część umów ma charakter $\mathrm{w}$ pełni oszczędnościowy, stąd pobieranie opłaty likwidacyjnej na tak wysokim poziomie zostało uznane za niedopuszczalne. Wysokość opłaty likwidacyjnej była przedmiotem orzeczenia Sądu Apelacyjnego w Warszawie z dnia 14 maja 2010 r., który uznał, że praktyka pobierania przez ubezpieczycieli opłaty likwidacyjnej w wysokości 100\% zgromadzonych środków stanowi niedozwolone postanowienie umowne [Szczepańska 2012: 3]. Podobne stanowisko prezentuje Rzecznik Finansowy, który zwraca uwagę, iż niejedno-

stosowały pełną eksternalizację. Tylko jeden zakład wykorzystywał wyłącznie zarządzanie wewnętrzne [Dopierała 2016: 127-147]. 
krotnie wysokość kosztów, w przypadku ubezpieczeń UFK, była nieadekwatna do faktycznych kosztów ponoszonych w zakładach ubezpieczeń [Ubezpieczenia na życie z ubezpieczeniowym funduszem kapitałowym]. Według stanu na koniec 2015 r. opłata likwidacyjna występowała w ubezpieczeniach działających jako IKE tylko w pierwszym roku trwania umowy. Jej wysokość była zróżnicowana w zależności od zakładu ubezpieczeń, jednak mogła wynosić nawet 50\% zgromadzonego kapitału. Biorąc jednak pod uwagę krótki okres opłacania składek oraz ich niską przeciętną wysokość, nawet tak wysoka procentowo opłata likwidacyjna, przekłada się w większości przypadków na stosunkowo niską wartość nominalną. Korzystne z punktu widzenia klienta, jest występowanie tejże opłaty tylko w pierwszym roku trwania umowy, co odróżnia ubezpieczenia z UFK oferowane $\mathrm{w}$ ramach IKE od większości polis typu unit-linked dostępnych na rynku.

\section{EFEKTYWNOŚĆ INWESTOWANIA OSZCZĘDNOŚCI EMERYTALNYCH W RAMACH UBEZPIECZENIOWYCH FUNDUSZY KAPITAŁOWYCH W LATACH 2005-2015}

Ponieważ w przypadku IKE oferowanych przez zakłady ubezpieczeń ryzyko oraz wynik działalności inwestycyjnej obciąża ubezpieczonego, istotnym zagadnieniem jest ocena efektywności inwestycyjnej UFK oferowanych w ramach tej formy zabezpieczenia emerytalnego. Zgodnie z klasyczną teorią portfela, inwestycja efektywna to taka, która przy danej stopie zwrotu minimalizuje ryzyko, lub przy założonym ryzyku maksymalizuje stopę zwrotu [Markowitz: 1952: 77-91]. W niniejszym artykule zaprezentowano wyniki badania efektywności inwestycyjnej UFK dostępnych w ramach IKE w latach 2005-2015. Długookresowa ocena efektywności inwestycyjnej ma bowiem największe znaczenie dla gromadzenia i pomnażania oszczędności emerytalnych. W ocenie uwzględniono17 funduszy akcji, 20 funduszy mieszanych oraz 19 funduszy obligacji prowadzonych przez następujące zakłady ubezpieczeń: Aviva TUnŻ, Generali Życie TU, NationalneNetherlanden TUnŻ, PKO Życie TU, PZU Życie, Skandia Życie TU5, STUnŻ Ergo Hestia, TU Allianz Życie Polska, TUnŻ Cardif Polska, TUnŻ SKOK oraz TUnŻ Warta. Fundusze podzielono na zarządzane wewnętrznie oraz zewnętrznie, by ocenić czy stosowana metoda zarządzania ma wpływ na osiągane wyniki inwestycyjne.

Pierwszym krokiem badania było obliczenie - na podstawie bazy danych wycen jednostek UFK - logarytmicznych miesięcznych stóp zwrotu poszczególnych funduszy. W badaniu zdecydowano się zastosować logarytmiczną stopę zwrotu ze względu na jej korzystne właściwości w tym w szczególności łatwość

\footnotetext{
${ }^{5}$ Skandia Życie TU funkcjonuje obecnie pod zmienioną nazwą Vienna Life TU na Życie S.A.
} 
wyliczenia zwrotu za okres dłuższy przez prostą agregację zwrotów z podokresów oraz przyjmowanie wartości z całej osi rzeczywistej [Doman i Doman 2009: 20]. Wyniki osiąganych średnich oraz skumulowanych stóp zwrotu obliczonych dla całego okresu badawczego na podstawie miesięcznych stóp zwrotu w poszczególnych grupach funduszy zaprezentowano w tab. 1.

Tabela 1. Charakterystyka skumulowanych oraz średnich miesięcznych logarytmicznych stóp zwrotu UFK wg typów funduszy za lata 2005-2015

\begin{tabular}{|c|c|c|c|c|c|c|c|}
\hline Typ UFK & $\begin{array}{l}\text { Liczba } \\
\text { UFK }\end{array}$ & Rodzaj stopy zwrotu & Średnia & $\begin{array}{l}\text { Odch. } \\
\text { stand. }\end{array}$ & Med. & Min & Max \\
\hline \multirow{2}{*}{$\begin{array}{l}\text { Akcji } \\
\text { zarządzane } \\
\text { wewnętrznie }\end{array}$} & \multirow[b]{2}{*}{2} & Skumulowana & 0,4515 & 0,1375 & 0,4515 & 0,3140 & 0,5890 \\
\hline & & $\begin{array}{l}\text { Średnia miesięczna } \\
\text { wyrażona w skali roku }\end{array}$ & 0,0414 & 0,0126 & 0,0414 & 0,0288 & 0,0540 \\
\hline \multirow{2}{*}{$\begin{array}{l}\text { Akcji } \\
\text { zarządzane } \\
\text { zewnętrznie }\end{array}$} & \multirow[b]{2}{*}{15} & Skumulowana & 0,3212 & 0,2739 & 0,3956 & $-0,4432$ & 0,6375 \\
\hline & & $\begin{array}{l}\text { Średnia miesięczna } \\
\text { wyrażona w skali roku }\end{array}$ & 0,0294 & 0,0251 & 0,0362 & $-0,0406$ & 0,0584 \\
\hline \multirow{2}{*}{$\begin{array}{l}\text { Mieszane } \\
\text { zarządzane } \\
\text { wewnętrznie }\end{array}$} & \multirow[b]{2}{*}{3} & Skumulowana & 0,4661 & 0,0374 & 0,4850 & 0,4138 & 0,4994 \\
\hline & & $\begin{array}{l}\text { Średnia miesięczna } \\
\text { wyrażona w skali roku }\end{array}$ & 0,0427 & 0,0034 & 0,0444 & 0,0379 & 0,0457 \\
\hline \multirow{2}{*}{$\begin{array}{l}\text { Mieszane } \\
\text { zarządzane } \\
\text { zewnętrznie }\end{array}$} & \multirow[b]{2}{*}{17} & Skumulowana & 0,3294 & 0,2326 & 0,3981 & $-0,2217$ & 0,5624 \\
\hline & & $\begin{array}{l}\text { Średnia miesięczna } \\
\text { wyrażona w skali roku }\end{array}$ & 0,0302 & 0,0213 & 0,0365 & $-0,0203$ & 0,0515 \\
\hline \multirow{2}{*}{$\begin{array}{l}\text { Obligacji } \\
\text { zarządzane } \\
\text { wewnętrznie }\end{array}$} & \multirow[b]{2}{*}{5} & Skumulowana & 0,3704 & 0,0765 & 0,3761 & 0,2388 & 0,4603 \\
\hline & & $\begin{array}{l}\text { Średnia miesięczna } \\
\text { wyrażona w skali roku }\end{array}$ & 0,0339 & 0,0070 & 0,0345 & 0,0219 & 0,0422 \\
\hline \multirow{2}{*}{$\begin{array}{l}\text { Obligacji } \\
\text { zarządzane } \\
\text { zewnętrznie }\end{array}$} & \multirow[b]{2}{*}{14} & Skumulowana & 0,4320 & 0,1080 & 0,4471 & 0,2388 & 0,6203 \\
\hline & & $\begin{array}{l}\text { Średnia miesięczna } \\
\text { wyrażona w skali roku }\end{array}$ & 0,0396 & 0,0099 & 0,0410 & 0,0219 & 0,0568 \\
\hline
\end{tabular}

Źródło: obliczenia własne na podstawie danych Analizy Online S.A.

W długim horyzoncie czasowym największą dochodowością charakteryzowały się UFK mieszane zarządzane wewnętrznie, dla których skumulowana logarytmiczna stopa zwrotu wyniosła przeciętnie 47\%. Wszystkie fundusze w tej grupie osiągnęły skumulowaną stopę zwrotu wyższą niż 40\%. Kolejne miejsce pod względem dochodowości zajęły fundusze akcji zarządzane wewnętrznie, gdzie średnio skumulowana stopa zwrotu wyniosła 45\%. Należy zaznaczyć, że w ramach IKE funkcjonowały tylko 2 UFK tego typu ${ }^{6}$. Kolejne miejsce w rankingu zajęły fundusze obligacji zarządzane zewnętrznie, gdzie przeciętnie skumulowana logarytmiczna stopa zwrotu wyniosła ponad 43\%. Połowa z 17 pod-

${ }^{6}$ Pomimo niewielkiej liczebności grup UFK akcji oraz mieszanych, zarządzanych wewnętrznie, aby zachować jednolitość prezentacji wyników i spójność prowadzonych rozważań, autor zdecydował się na prezentację podstawowych statystyk opisowych dla rozkładów stóp zwrotu oraz wskaźników efektywności w tych grupach. 
danych analizie funduszy osiągnęła skumulowaną dochodowość wyższą niż $44 \%$. UFK obligacji zarządzane wewnętrznie osiągały średnio skumulowane stopy zwrotu na poziomie $37 \%$.

Najsłabsze wyniki osiągnęły średnio UFK mieszane zarządzane zewnętrznie oraz akcji zarządzane zewnętrznie. W obu grupach przeciętna skumulowana dochodowość wynosiła powyżej $32 \%$. Związane to było $\mathrm{z}$ występowaniem w obu grupach funduszy, które w ciągu 11 lat przyniosły stratę (w przypadku funduszu akcji o najsłabszej dochodowości wyniosła ona ponad $44 \%$, a w przypadku funduszu mieszanego o najsłabszej dochodowości - 22\%). Warto jednak dodać, że w grupie UFK akcji zarządzanych zewnętrznie znalazł się także fundusz najbardziej dochodowy, ze skumulowaną stopą zwrotu w wysokości $63 \%$. Dla porównania warto dodać, że w tym samym okresie skumulowana logarytmiczna stopa zwrotu liczona na podstawie zmian indeksu WIG wyniosła $58 \%{ }^{7}$.

Aby ocenić efektywność inwestycji, wykorzystano wskaźnik Sharpe’a. Jest to najczęściej stosowany przez praktyków gospodarczych wskaźnik efektywności inwestycyjnej. Do jego zalet należą przede wszystkim prostota konstrukcji oraz łatwość interpretacji wyników przez klientów instytucji finansowych. Wskaźnik Sharpe'a najlepiej zatem koresponduje z celem artykułu, jakim jest ocena efektywności IKE z punktu widzenia klientów ${ }^{8}$. Został on skonstruowany przez W. F. Sharpe'a [1966: 119-138] i nazwany współczynnikiem premii za zmienność. Chociaż nazwa zaproponowana przez twórcę wskaźnika nie jest powszechnie używana, oddaje dokładnie ideę jaką się on kierował. Wskaźnik wyraża się bowiem wzorem:

$$
S_{p t}=\frac{R_{p t}-R_{f t}}{\sigma_{p t}}
$$

gdzie:

$S_{p t} \quad$ - wskaźnik Sharpe'a dla portfela $p$ obliczony dla okresu $t$;

$R_{p t} \quad$ - średnia stopa zwrotu portfela $p$ w okresie $t$

$R_{f t} \quad-$ średnia wartość stopy zwrotu bez ryzyka w okresie $t$;

$\sigma_{p t} \quad$ - odchylenie standardowe stopy zwrotu portfela $p$ w okresie $t$.

\footnotetext{
${ }^{7}$ Obliczenia własne na podstawie danych Thomson Reuters uzyskanych na podstawie umowy o współpracy między Thomson Reuters a Uniwersytetem Gdańskim.

${ }^{8}$ Wyniki uzyskane za pomocą wskaźnika Sharpe'a są najbardziej miarodajne, gdy rozkład osiąganych stóp zwrotu nie odbiega znacznie od rozkładu normalnego. Badania empiryczne prowadzone przez Elinga i Schuhmachera [2007: 2632-2647] wskazują jednak, że brak normalności rozkładu stóp zwrotu nie wpływa istotnie na pozycję funduszu w rankingu, a średnia i wariancja (odchylenie standardowe) opisują w takich przypadkach rozkład wystarczająco dobrze. W rozważaniach zdecydowano się zatem pominąć aspekt rozkładu stóp zwrotu.
} 
Odnosi on zatem nadwyżkową stopę zwrotu do ogólnego ryzyka inwestycyjnego, które mierzone jest odchyleniem standardowym.

Do obliczenia wskaźnika Sharpe'a dla UFK wykorzystano miesięczne logarytmiczne stopy zwrotu. Jako stopę zwrotu wolną od ryzyka przyjęto średnią miesięczną stawkę referencyjną POLONIA, która została zlogarytmizowana. Wyniki obliczeń dla poszczególnych grup UFK zaprezentowano w tab. 2.

Tabela 2. Charakterystyka wskaźnika Sharpe'a UFK dostępnych w ramach IKE według typów funduszy

\begin{tabular}{|l|c|c|c|c|c|c|}
\hline Typ UFK & $\begin{array}{c}\text { Liczba } \\
\text { UFK }\end{array}$ & Średnia & Odch. stand. & Mediana & Min & Max \\
\hline $\begin{array}{l}\text { Akcji zarządzane } \\
\text { wewnętrznie }\end{array}$ & 2 & 0,0072 & 0,0225 & 0,0072 & $-0,0153$ & 0,0297 \\
\hline $\begin{array}{l}\text { Akcji zarządzane } \\
\text { zewnętrznie }\end{array}$ & 15 & $-0,0097$ & 0,0338 & $-0,0017$ & $-0,0957$ & 0,0317 \\
\hline $\begin{array}{l}\text { Mieszane } \\
\text { zarządzane } \\
\text { wewnętrznie }\end{array}$ & 3 & 0,0221 & 0,0139 & 0,0313 & 0,0024 & 0,0327 \\
\hline $\begin{array}{l}\text { Mieszane zarzą- } \\
\text { dzane zewnętrznie }\end{array}$ & 17 & $-0,0142$ & 0,0485 & $-0,0021$ & $-0,1192$ & 0,0518 \\
\hline $\begin{array}{l}\text { Obligacji } \\
\text { zarządzane } \\
\text { wewnętrznie }\end{array}$ & 5 & $-0,1260$ & 0,1648 & $-0,0861$ & $-0,3990$ & 0,0486 \\
\hline $\begin{array}{l}\text { Obligacji zarzą- } \\
\text { dzane zewnętrznie }\end{array}$ & 14 & $-0,0029$ & 0,1377 & 0,0168 & $-0,3990$ & 0,1622 \\
\hline
\end{tabular}

Źródło: obliczenia własne na podstawie danych Analizy Online S.A. oraz Thomson Reuters pozyskanych na podstawie umowy o współpracy między Thomson Reuters a Uniwersytetem Gdańskim.

W latach 2005-2015 we wszystkich badanych UFK zarządzanych zewnętrznie oraz UFK obligacji zarządzanych wewnętrznie przeciętna wartość wskaźnika była ujemna. Oznacza to, że osiągały one średnio niższe stopy zwrotu, niż założona stopa wolna od ryzyka. Dodatnia przeciętna wartość wskaźnika wystąpiła w przypadku funduszy akcji oraz mieszanych zarządzanych wewnętrznie. Dla porównania wskaźnik Sharpe'a liczony tą samą metodą dla tego samego okresu w przypadku indeksu WIG wyniósł 0,0182. Oznacza to, że żadna grupa UFK średnio nie osiągnęła efektywności pasywnego portfela opartego na polskim rynku akcji.

Należy zwrócić uwagę na niską wartość wskaźnika dla UFK obligacji zarządzanych wewnętrznie w latach 2005-2015. Wynika ona $z$ osiągania niskich zysków oraz jednocześnie z niższej niż w pozostałych grupach zmienności stóp zwrotu funduszu. Istnieją jednak UFK, dla których efektywność można uznać za zadowalającą lub nawet ponadprzeciętną. Dla przykładu wśród UFK mieszanych 
zarządzanych wewnętrznie dwa najlepsze fundusze osiągnęły wartość wskaźnika wyższą niż 0,0313. W każdej grupie najlepsze UFK osiągały efektywność zdecydowanie wyższą, niż efektywność pasywnego portfela opartego o indeks WIG. Co ciekawe, największa zmienność wskaźnika wystąpiła w przypadku UFK obligacji.

\section{PODSUMOWANIE}

Pośród trzech form dodatkowego zabezpieczenia dostępnych w polskim systemie emerytalnym, najpowszechniej wykorzystywaną jest indywidualne konto emerytalne. Może być ono prowadzone w instytucjach takich jak banki, biura maklerskie, towarzystwa funduszy inwestycyjnych, powszechne towarzystwa emerytalne oraz zakłady ubezpieczeń. W ostatniej z wymienionych instytucji prowadzonych jest największa liczba kont - ponad 570 tys.

Ponieważ indywidualne konta emerytalne prowadzone przez zakłady ubezpieczeń łączą W sobie dwie funkcje: oszczędnościowo-inwestycyjną oraz ochronną, przy czym druga z nich ma marginalne znaczenie, pojawia się pytanie, czy z punktu widzenia osoby gromadzącej oszczędności emerytalne takie rozwiązanie jest korzystne? Przeprowadzone badania wskazują, że oferowane produkty mają bardzo złożoną konstrukcję, co nie jest pożądaną cechą produktów emerytalnych. Proponowana minimalna ochrona ubezpieczeniowa generuje natomiast dodatkowe koszty.

Funkcjonujące w ramach IKE ubezpieczeniowe fundusze kapitałowe w większości są funduszami zarządzanymi zewnętrznie, nabywającymi jednostki uczestnictwa funduszy inwestycyjnych otwartych. Liczba funkcjonujących funduszy zarządzanych wewnętrznie jest niewielka, a przy tym nie zaobserwowano, by wykazywały się one regularnie wyższą efektywnością, niż fundusze zarządzane zewnętrznie.

Należy dodać, że indywidualne konta emerytalne oferowane jako ubezpieczeniowy produkt inwestycyjny mają co prawda pewne unikalne zalety, takie jak $\mathrm{np}$. brak konieczności przeprowadzania postępowania spadkowego w przypadku śmierci osoby ubezpieczonej, czy częściowa ochrona przed egzekucją sądową. $\mathrm{Z}$ punktu widzenia większości osób gromadzących oszczędności emerytalne są to jednak cechy mało istotne.

Powyższa charakterystyka indywidualnych kont prowadzonych przez zakłady ubezpieczeń wskazuje, że oferowanie ich jako samodzielnych produktów ubezpieczeniowych należy uznać za rozwiązanie mało korzystne z punktu widzenia osób gromadzących oszczędności emerytalne. Nie dają one bowiem żadnych wyraźnych korzyści w stosunku do np. kont prowadzonych przez towarzystwa funduszy inwestycyjnych czy też powszechne towarzystwa emerytalne. 
W opinii autora uzasadnionym może być oferowanie kont w formie dodatkowej umowy do już posiadanego ubezpieczenia, bądź pakietu ubezpieczeń na życie. Tego typu produkty nie wiążą się z dodatkowymi kosztami, gdyż koszt ochrony ubezpieczeniowej i tak już zostaje poniesiony. Zachowana zostaje podstawowa funkcja ochronna ubezpieczenia, a konto staje się dodatkiem do produktu, zachęcającym do gromadzenia oszczędności emerytalnych, co jest niewątpliwie korzystne również z punktu widzenia całego systemu emerytalnego.

\section{BIBLIOGRAFIA}

Doman M., Doman R., 2009, Modelowanie zmienności i ryzyka. Metody ekonometrii finansowej, Oficyna Wolters Kluwer Business, Kraków.

Dopierała Ł., 2016, Polityka inwestycyjna zakładów ubezpieczeń $w$ ramach indywidualnych kont emerytalnych, „Ubezpieczenia Społeczne. Teoria i praktyka”, $\mathrm{nr} 2$.

Eling M., Schuhmacher F., 2007, Does the Choice of Performance Measure Influence the Evaluation of Hedge Funds?, „Journal of Banking \& Finance”, vol. 31, nr 9.

Holzmann R., 1998, A World Bank Perspective on Pension Reform. World Bank, Social Protection Group, Human Development Network.

Kania P., 2011, Specjalistyczne fundusze inwestycyjne otwarte jako forma zewnętrznego zarzadzania ubezpieczeniowymi funduszami kapitałowymi zakładów ubezpieczeń na życie, „Prace Naukowe Uniwersytetu Ekonomicznego we Wrocławiu", nr 228.

Komisja Nadzoru Finansowego, http://www.knf.gov.pl

Kucharski B., 2015, Ochrona spadkobierców, uprawnionych do zachowku oraz wierzycieli w razie wskazania uposażonego w umowie ubezpieczenia na życie, „Prawo Asekuracyjne”, nr 1.

Markowitz H., 1952, Portfolio Selection, „The Journal of Finance”, vol. 7, nr 1.

Rozporządzenie Ministra Finansów z dnia 12 kwietnia 2016 r. w sprawie szczególnych zasad rachunkowości zakładów ubezpieczeń i zakładów reasekuracji, Dz.U. 2016, poz. 562.

Sharpe W. F., 1966, Mutual Fund Performance, „The Journal of Business”, vol. 39, nr 1.

Szczepańska M., 2011, Ubezpieczenie na życie z ubezpieczeniowym funduszem kapitatowym, Wolters Kluwer, Warszawa.

Szczepańska M, 2012, Charakterystyka prawna optaty likwidacyjnej pobieranej przez ubezpieczycieli w umowie ubezpieczenia na życie z ubezpieczeniowym funduszem kapitałowym, „Wiadomości Ubezpieczeniowe", $\mathrm{nr} 1$.

Szczepański M., 2012, The Design of Supplementary Pension Schemes in Poland and Longevity Risk: Current Situation and Proposed Changes, „Pensions Institute Discussion Paper”, styczeń.

Ubezpieczenia na życie z ubezpieczeniowym funduszem kapitałowym - raport Rzecznika Finansowego, 2016, Rzecznik Finansowy, Warszawa.

Ustawa z dnia 23 kwietnia 1964 r. Kodeks cywilny, tekst jednolity, Dz.U. 2016, poz. 380, 585 $\mathrm{z}$ późn. $\mathrm{zm}$.

Ustawa z dnia 22 maja 2003 r. o ubezpieczeniach obowiązkowych, Ubezpieczeniowym Funduszu Gwarancyjnym i Polskim Biurze Ubezpieczycieli Komunikacyjnych, tekst jednolity, Dz.U. 2013, poz. 392 z późń. zm.

Ustawa z dnia 20 kwietnia 2004 r. o indywidualnych kontach emerytalnych, Dz.U. 2004, nr 116, poz. 1205 . 
Ustawa z dnia 20 kwietnia 2004 r. o indywidualnych kontach emerytalnych oraz indywidualnych kontach zabezpieczenia emerytalnego, tekst jednolity, Dz.U. 2014, poz. 1147 z późn. zm.

Ustawa z dnia 6 listopada 2008 r. o zmianie ustawy o indywidualnych kontach emerytalnych oraz niektórych innych ustaw, Dz.U. 2008, nr 220, poz. 1432.

Ustawa z dnia 11 września 2015 r. o działalności ubezpieczeniowej i reasekuracyjnej, Dz.U. 2015, poz. 1844 z późn. zm.

\title{
EFFICIENCY OF PENSION PRODUCTS OFFERED BY LIFE INSURANCE COMPANIES. THE CASE OF INDIVIDUAL PENSION ACCOUNTS
}

\begin{abstract}
The purpose of this article is to determine the efficiency of pension products offered by life insurance companies. The article presents the significance of the products offered by insurance companies in the Polish pension system. Moreover, it characterize the functioning of individual pension accounts offered by insurers from the consumer point of view. In addition, the paper presents the investment efficiency achieved by the insurance capital funds operating within individual pension accounts during the period 2005-2015. The conducted studies also shows that individual pension accounts run as separate insurance products are not a good solution from the perspective of persons gathering pension savings.
\end{abstract}

Keywords: IKE, pension, insurance, efficiency, funds. 